\title{
PERBANDINGAN MATERI MUATAN KETETAPAN MPR PADA MASA PEMERINTAHAN ORDE LAMA, ORDE BARU, DAN ERA REFORMASI ${ }^{1}$
}

\author{
Widayati \\ Dosen Fakultas Hukum UNISSULA \\ widayati.winanto@gmail.com
}

\begin{abstract}
Decree of People's Consultative Assembly (TAP MPR) established since 1960 and 2002. Totally there are 139 Decrees in Consultative Assembly (TAP MPRS and TAP MPR). The whole Decree of People's Consultative Assembly (TAP MPRS and TAP MPR) was formed during the reign of the Old Orde, the New Orde, and the Reformation Era. TAP MPR was changed in content material along with the change of government and the amendments of 1945 Constitution of The State of The Republic of Indonesia (UUD 1945). Therefore, this study will compare to the substance of the Decree of People's Consultative Assembly (TAP MPR) on the government period.

The method used in this research was normative juridical with secondary data, which was analyzed by the method of normative, then presented descriptively. The change of government affects the substance of the Decree of People's Consultative Assembly (TAP MPR).
\end{abstract}

Keywords: Content Material, Decree of People's Consultative Assembly (TAP MPR).

\begin{abstract}
Abstrak
Ketetapan Majelis Permusyawaratan Rakyat (TAP MPR) didirikan sejak tahun 1960 dan 2002, total 139 Ketetapan Majelis Permusyawaratan Rakyat (TAP MPRS dan TAP MPR). Seluruh Ketetapan Majelis Permusyawaratan Rakyat (TAP MPRS dan TAP MPR) dibentuk pada masa pemerintahan Lama Orde, Orde Baru, dan Era Reformasi. Ketetapan Majelis Permusyawaratan Rakyat (TAP MPR) bahan isi yang berbeda bersama dengan perubahan dalam pemerintahan dan amandemen UUD 1945 Negara Republik Indonesia (UUD 1945). Oleh karena itu, dalam penelitian ini akan dibandingkan dengan substansi Ketetapan Majelis Permusyawaratan Rakyat (TAP MPR) pada periode pemerintah. Metode yang digunakan dalam penelitian ini adalah yuridis normatif dengan data sekunder, yang dianalisis dengan metode normatif, kemudian disajikan secara deskriptif. Perubahan pemerintahan mempengaruhi substansi Ketetapan Majelis Permusyawaratan Rakyat (TAP MPR).
\end{abstract}

Kata kunci: Kandungan Material, Ketetapan Majelis Permusyawaratan Rakyat (TAP MPR).

\section{A. Pendahuluan}

Bentuk produk hukum Ketetapan MPR tidak dinyatakan secara tegas dalam UUD 1945. Penggunaan nomenklatur "ketetapan" merupakan penafsiran terhadap ketentuan Pasal 3 UUD 1945 (sebelum amandemen) yang menyatakan bahwa: "Majelis Permusyawaratan Rakyat berwenang menetapkan Undang-Undang Dasar dan garis- garis besar daripada haluan negara". Berdasarkan kata "menetapkan" dari bunyi Pasal 3 tersebut maka ketika MPR mengeluarkan produk hukum diberi bentuk "ketetapan". Bentuk Ketetapan MPR berkembang dalam praktik ketatanegaraan yang menjadi konvensi ketatanegaraan.

Pada masa berlakunya Undang-Undang Dasar 1945 yang pertama (1945-1949), Ketetapan

1 Tulisan ini adalah sebagian dari disertasi penulis pada Program Doktor IImu Hukum, Sekolah Pascasarjana Universitas Muhammadiyah Surakarta, 2015. 
MPR belum dikenal karena lembaga MPR sendiri memang belum terbentuk. Begitu pula pada masa berlakunya Konstitusi Republik Indonesia Serikat 1949 (1949-1950) dan Undang-Undang Dasar Sementara 1950 (1950-1959), Ketetapan MPR tidak dikenal karena dalam Konstitusi RIS 1949 dan UUDS 1950 tidak dikenal lembaga MPR.

Ketetapan MPR mulai dikenal pada tahun 1960 pada masa berlakunya kembali Undang-Undang Dasar 1945 berdasarkan Dekrit Presiden 5 Juli 1959. Pada saat pertama kali Ketetapan MPRS dibentuk, di Indonesia belum mengenal hierarki peraturan perundang-undangan, sehingga tidak ada perdebatan para ahli mengenai penempatan Ketetapan MPR, apakah sejajar dengan UndangUndang Dasar 1945 atau setingkat lebih rendah dari Undang-Undang Dasar 1945.

Jenis produk hukum yang dikeluarkan oleh MPR sebelum MPR hasil pemilihan umum tahun 1971 terbentuk bermacam-macam. MPR dalam melakukan sidang akan diakhiri dengan suatu keputusan. Keputusan-keputusan MPR yang dihasilkan dari sidang-sidang MPR ada yang disebut dengan ketetapan, keputusan atau dengan nama-nama lain seperti nota pimpinan, memorandum, dan sebagainya. Produk hukum MPR yang berupa ketetapan mengacu pada ketentuan Pasal 3 Undang-Undang Dasar 1945 (sebelum amandemen), bahwa MPR menetapkan Undang-Undang Dasar dan garis-garis besar dari pada haluan negara.

Di dalam praktiknya, MPR mengeluarkan produk hukum yang berupa ketetapan tidak hanya terbatas pada apa yang dirumuskan dalam Pasal 3 Undang-Undang Dasar 1945, yaitu untuk Undang-Undang Dasar dan garisgaris besar haluan negara, tetapi produk hukum Ketetapan MPR juga memuat materi muatan bidang-bidang lainnya dan tidak tampak jelas bedanya dengan Keputusan MPR. ${ }^{2}$

Ketidakjelasan penggunaan istilah ketetapan MPR dan keputusan MPR dapat mengaburkan tujuan serta pengertian masing-masing. Jika arti ketetapan MPR itu berbeda dengan keputusan MPR, karena menurut Pasal 3 Undang-Undang

2 Moh. Kusnardi dan Bintan R. Saragih, 1980, Susunan Pembagian Kekuasaan Menurut Sistem Undang-Undang Dasar 1945, Gramedia, Jakarta, hIm. 49.
Dasar 1945 Ketetapan MPR hanya untuk produk hukum yang materi muatannya adalah UndangUndang Dasar dan garis-garis besar dari pada haluan negara, sebaiknya hal-hal yang berada di luar Pasal 3 Undang-Undang Dasar 1945 tidak digunakan istilah ketetapan MPR tetapi digunakan istilah Keputusan MPR. ${ }^{3}$

Untuk memperjelas produk hukum yang dikeluarkan oleh MPR, setelah MPR hasil pemilihan umum tahun 1971 terbentuk, MPR mengeluarkan Ketetapan MPR Nomor I/ MPR/1973 tentang Peraturan Tata Tertib Majelis Permusyawaratan Rakyat. Dalam Pasal 102 Ketetapan MPR Nomor I/MPR/1973 ditentukan bahwa bentuk-bentuk putusan Majelis adalah Ketetapan Majelis Permusyawaratan Rakyat dan Keputusan Majelis Permusyawaratan Rakyat. Daya mengikat kedua produk hukum MPR tersebut berbeda. Ketetapan Majelis Permusyawaratan Rakyat adalah Putusan Majelis yang mempunyai kekuatan hukum mengikat ke luar dan ke dalam, sedangkan Keputusan Majelis Permusyawaratan Rakyat adalah Putusan Majelis yang mempunyai kekuatan hukum mengikat ke dalam Majelis.

Produk hukum yang berupa Ketetapan MPR dibentuk atau dikeluarkan oleh MPR dalam beberapa periode jabatan melalui Sidang Umum dan Sidang Istimewa MPR sejak tahun 1960 sampai dengan tahun 2003 yang menghasilkan 139 Ketetapan MPRS dan Ketetapan MPR. Materi muatan Ketetapan MPRS dan Ketetapan MPR berubah, seiring dengan bargantinya pemerintahan, dan berubahnya Undang-Undang Dasar yang berlaku di Indonesia. Berdasarkan uraian di atas, masalah yang dibahas dalam penelitian ini adalah bagaimanakah materi muatan Ketetapan MPR pada masa pemerintahan Orde Lama, Orde Baru, dan Era Reformasi.

\section{B. Pembahasan}

Materi muatan peraturan perundangundangan adalah materi yang dimuat dalam Peraturan Perundang-undangan sesuai dengan jenis, fungsi, dan hierarki Peraturan Perundangundangan. ${ }^{4}$ Istilah materi muatan pertama kali

3 Ibid.

4 Pasal 1 angka 13 Undang-Undang Nomor 12 Tahun 2011 tentang Pembentukan Peraturan Perundangundangan. 
dikemukakan oleh A. Hamid S. Attamimi yang digunakan sebagai pengganti kata Belanda "het onderwerp" ${ }^{5}$

Setiap peraturan perundang-undangan mengatur materi muatan yang berbeda-beda sesuai dengan jenis dan hierarkinya. Suatu peraturan perundang-undangan yang materinya tidak sesuai atau bertentangan dengan peraturan perundang-undangan yang lebih tinggi dapat menjadi alasan untuk membatalkan peraturan perundang-undangan tersebut. Undang-Undang Nomor 12 Tahun 2011 mengatur mengenai materi muatan setiap jenis peraturan perundangundangan. Materi muatan yang harus diatur dengan Undang-Undang. ${ }^{6}$

a. Pengaturan lebih lanjut mengenai ketentuan Undang-Undang Dasar Negara Republik Indonesia Tahun 1945;

b. Perintah suatu Undang-Undang untuk diatur dengan Undang-Undang;

c. Pengesahan perjanjian internasional tertentu; ${ }^{7}$

d. Tindak lanjut atas putusan Mahkamah Konstitusi; dan/atau

5 A. Hamid S. Attamimi, Peranan Keputusan Presiden Republik Indonesia dalam Penyelenggaraan Pemerintahan Negara, Suatu Studi Analisis Mengenai Keputusan Presiden yang Berfungsi Pengaturan dalam Kurun Waktu Pelita I - Pelita IV, Disertasi untuk memperoleh Gelar Doktor dalam IImu Hukum pada Universitas Indonesia Fakultas Pascasarjana, Jakarta, 1990, hal. 194. Istilah "materi muatan" pertama kali diperkenalkan oleh A. Hamid S. Attamimi pada tahun 1979 dalam kajiannya mengenai "Materi muatan peraturan perundangundangan". Kata "materi muatan" digunakan sebagai pengganti kata Belanda "het onderwerp" dalam ungkapan Thorbecke "het eiqenaardiq onderwerp der wet". A. Hamid S. Attamimi menterjemahkannya dengan "materi muatan yang khas dari undangundang", yakni materi pengaturan yang khas yang hanya dan semata-mata dimuat dalam undangundang dan oleh katena itu menjadi materi muatan undang-undang.

6 Pasal 10 Undang-Undang Nomor 12 Tahun 2011 tentang Pembentukan Peraturan Perundangundangan

7 Perjanjian Internasional tertentu menurut penjelasan Undang-undang Nomor 12 Tahun 2011 adalah perjanjian internasional yang menimbulkan akibat yang luas dan mendasar bagi kehidupan rakyat yang terkait dengan beban keuangan negara dan/atau perjanjian tersebut mengharuskan perubahan atau pembentukan Undang-Undang dengan persetujuan DPR. e. Pemenuhan kebutuhan hukum dalam masyarakat.

Materi muatan Peraturan Pemerintah Pengganti Undang-Undang sama dengan materi muatan Undang-Undang. Bedanya adalah kalau Undang-Undang dibentuk dalam keadaan normal, sedangkan Peraturan Pemerintah Pengganti Undang-Undang dibentuk dalam keadaan genting. ${ }^{8}$ Materi muatan Peraturan Pemerintah berisi materi muatan untuk menjalankan UndangUndang sebagaimana mestinya. Materi muatan Peraturan Presiden merupakan materi yang diperintahkan oleh Undang-Undang, materi untuk melaksanakan Peraturan Pemerintah, atau materi untuk melaksanakan penyelenggaraan kekuasaan pemerintahan. Materi muatan Peraturan Daerah (Provinsi dan Kabupaten/Kota) adalah materi muatan dalam rangka penyelenggaraan otonomi dan tugas pembantuan serta menampung kondisi khusus daerah dan/atau penjabaran lebih lanjut Peraturan Perundang-undangan yang lebih tinggi.

Materi muatan peraturan perundangundangan harus mencerminkan asas-asas Pengayoman, Kemanusiaan, Kebangsaan, Kekeluargaan, Kenusantaraan, Bhineka Tunggal Ika, Keadilan, Kesamaan kedudukan dalam hukum dan pemerintahan, Ketertiban dan kepastian hukum, serta Keseimbangan, keserasian, dan keselarasan.

Undang-Undang Nomor 12 Tahun 2011 tidak mengatur materi muatan Ketetapan MPR. Hal ini dapat dipahami karena menurut UndangUndang Nomor 12 Tahun 2011, Ketetapan MPR secara hierarki kedudukannya lebih tinggi dari pada Undang-Undang sehingga Undang-Undang yang kedudukannya lebih rendah tidak dapat mengatur mengenai materi muatan Ketetapan MPR.

Materi muatan Ketetapan MPR yang dibentuk mulai tahun 1960 sampai tahun 2002 berbedabeda. Tidak ada ketentuan mengenai materi apa saja yang dapat dimuat dalam Ketetapan 8 Pasal 22 Undang-Undang Dasar Negara Republik Indonesia Tahun 1945: (1) Dalam hal-ihwal kegentingan yang memaksa, Presiden berhak menetapkan peraturan pemerintah pengganti undang-undang. (2) Peraturan Pemerintah itu harus mendapat persetujuan Dewan Perwakilan Rakyat dalam persidangan yang berikut. (3) Jika tidak mendapat persetujuan, maka peraturan pemerintah itu harus dicabut. 
MPR. Semua materi muatan dapat dituangkan dalam Ketetapan MPR sesuai dengan keinginan MPR, tidak terbatas pada materi yang bersifat pengaturan ataupun penetapan (beschikking). Kedudukannya sebagai lembaga tertinggi negara menyebabkan MPR mempunyai kewenangan yang tidak terbatas. ${ }^{9}$ Padahal sebenarnya, berdasarkan kewenangan yang dimiliki oleh MPR dalam UUD 1945, materi muatan Ketetapan MPR hanyalah materi muatan untuk menetapkan garis-garis besar daripada haluan negara, pengangkatan dan pemberhentian Presiden dan Wakil Presiden. Untuk kewenangan menetapkan Undang-Undang Dasar tidak dilakukan lagi karena UUD 1945 sudah ditetapkan oleh PPKI pada tanggal 18 Agustus 1945, dan oleh Presiden melalui Dekrit Presiden tanggal 5 Juli 1959 yang memberlakukan kembali UUD 1945.

\section{Materi Muatan Ketetapan MPRS Masa Pemerintahan Orde Lama}

Pembentukan MPRS pertama kali dilakukan dengan Penetapan Presiden Nomor 2 Tahun 1959 tanggal 22 Juli 1959. Pembentukan MPRS ini merupakan perintah Dekrit Presiden tanggal 5 Juli 1959, yang salah satu isinya adalah "Pembentukan Majelis Permusyawaratan Rakyat Sementara yang terdiri atas anggota-anggota Dewan Perwakilan Rakyat ditambah dengan utusan-utusan dari daerah-daerah dan golongan-golongan serta pembentukan Dewan Pertimbangan Agung Sementara, akan diselenggarakan dalam waktu yang sesingkat-singkatnya."

Pada masa pemerintahan Orde Lama, terdapat dua periode keanggotaan MPRS yaitu MPRS Periode 1960-1965, dan MPRS periode 1966-1972. Ketetapan MPRS yang dihasilkan oleh MPRS periode 1960-1965, terdapat Ketetapan MPRS yang materi muatannya berupa pengaturan, dan ada pula materi muatan yang berupa penetapan.

9 Penjelasan Pasal 3 UUD 1945 menyatakah: "Oleh karena Majelis Permusyawaratan Rakyat memegang kedaulatan negara maka kekuasaannya tidak terbatas, mengingat dinamik masyarakat, sekali dalam 5 tahun, Majelis memperhatikan segala yang terjadi dan segala aliran-aliran pada waktu itu dan menentukan haluan-haluan apa yang hendaknya dipakai untuk di kemudian hari".
Bahkan terdapat materi muatan Ketetapan MPRS yang hanya merupakan penegasan kembali pidato Presiden. Hal ini terjadi karena MPRS pembentukannya dengan Penetapan Presiden sehingga MPRS periode ini bukan sebagai pemegang kedaulatan rakyat sebagaimana diamanatkan UUD 1945. Bahkan, Ketua MPRS (Chairul Saleh) diangkat sebagai Wakil Perdana Menteri yang kedudukannya berada di bawah Presiden. Posisi ini jelas menempatkan lembaga MPRS berada di bawah Presiden sehingga Presiden tidak bertanggungjawab kepada MPRS, yang berarti sistem ketatanegaraan seperti ini tidak sesuai dengan maksud UUD 1945. Meskipun demikian, hubungan antara MPRS dengan Presiden dapat dikatakan harmonis.

Materi muatan Ketetapan MPRS yang merupakan penegasan kembali pidato Presiden.

a. Ketetapan MPRS Nomor I/MPRS/1960 tentang Manifesto Politik Republik Indonesia Sebagai Garis-Garis Besar dari pada Haluan Negara, merupakan penegasan dari pidato Presiden yang berjudul "Penemuan Kembali Revolusi Kita" yang terkenal sebagai Manifesto Politik Republik Indonesia (merupakan amanat Presiden yang disampaikan pada tanggal 17 Agustus 1959), pidato Presiden yang berjudul "Jalannya Revolusi Kita” yang merupakan pedoman pertama Manifesto Politik Republik Indonesia (merupakan amanat Presiden yang disampaikan pada tanggal 17 Agustus 1960), pidato Presiden yang berjudul "The Build the world a new" (membangun dunia kembali) yang disampikan di muka Sidang Umum PBB pada tanggal 30 September 1960.

b. Ketetapan MPRS Nomor IV/ MPRS/1963 tentang Pedomanpedoman Pelaksanaan GarisGaris Besar Haluan Negara dan Haluan Pembangunan, merupakan penegasan pidato Presiden yang 
berjudul "Resopim" (RevolusiSosialisme Indonesia Pimpinan Nasional, pidato kenegaraan yang disampaikan oleh Presiden pada tanggal 17 Agustus 1961) dan pidato Presiden yang berjudul "Tahun Kemenangan" (Takem, pidato kenegaraan yang disampaikan oleh Presiden pada taanggal 17 Agustus 1962), "Deklarasi Ekonomi" (Dekon), diucapkan oleh Presiden pada tanggal 28 Maret 1963) dan "Ambeg Parama Arta" (Berwatak pandai mendahulukan urusan yang penting, amanat pengantar Laporan Berkala Presiden/Mandataris MPRS yang diucapkan oleh Presiden pada pembukaan Sidang kedua MPRS pada tanggal 15 Mei 1963 di Bandung).

c. Ketetapan MPRS Nomor V/ MPRS/1965 tentang Amanat Politik Presiden/Pemimpin Besar Revolusi/ Mandataris MPRS yang berjudul "Berdikari" sebagai Penegasan Revolusi Indonesia dalam bidang Politik, Pedoman Pelaksanaan Manipol dan Landasan Program Perjuangan Rakyat Indonesia, materi muatannya didasarkan pada amanat politik Presiden yang berjudul "Berdiri di atas Kaki Sendiri" (Berdikari, merupakan amanat Presiden yang disampaikan pada Pembukaan Sidang Umum MPRS Ketiga pada tanggal 11 April 1965).

d. Ketetapan MPRS Nomor VI/ MPRS/1965 tentang Banting Stir untuk Berdiri di atas Kaki Sendiri di bidang Ekonomi dan Pembangunan, materi muatannya didasarkan pada amanat politik Presiden yang berjudul "Berdikari".

e. Ketetapan MPRS Nomor VII/ MPRS/1965 tentang "GESURl", "TAVIP", "The Fifth Freedom is our Weapon", dan "The Era of Confrontation" sebagai Pedomanpedoman Pelaksanaan Manifesto
Politik Republik Indonesia, materi muatannya berdasarkan pada empat pidato Presiden yaitu: pertama, pidato berjudul "GESURI" (Genta Revolusi Indonesia, pidato kenegaraan yang disampaikan oleh Presiden pada tanggal 17 Agustus 1963). Kedua, pidato yang berjudul "TAVIP" (Tahun Vivere Pericoloso, pidato kenegaraan yang disampaikan oleh Presiden pada tanggal 17 Agustus 1964). Ketiga, pidato yang berjudul "The Fifth Freedom is our Weapon" (diucapkan oleh Presiden di depan musyawarah para menteri negara-negara Asia Afrika pada tanggal 10 April 1964). Keempat, pidato yang berjudul "The Era of Confrontation" (diucapkan oleh Presiden di Konferensi Tingkat Tinggi nonblok kedua di Kairo pada tanggal 6 Oktober 1964).

Materi muatan Ketetapan MPRS yang hanya merupakan penegasan kembali pidato Presiden menempatkan MPRS sekedar sebagai legislator dari haluanhaluan yang disampaikan oleh Presiden dalam pidatonya yang berupa manifesto politik, haluan pembangunan, Pemimpin Besar Revolusi, dan sebagainya.

Pada masa ini juga terdapat materi muatan Ketetapan MPRS yang bertentangan dengan UUD 1945, yaitu Ketetapan MPRS Nomor III/MPRS/1963 tentang Pengangkatan Pemimpin Besar Revolusi Indonesia Bung Karno menjadi Presiden Seumur Hidup. Hal ini bertentangan dengan ketentuan Pasal 7 UUD 1945 yang membatasi masa jabatan Presiden selama 5 (lima) tahun. ${ }^{10}$ Pengangkatan Bung Karno sebagai Presiden seumur hidup didasarkan pada beberapa pertimbangan berikut ini.

a. Presiden Soekarno telah diangkat menjadi Pemimpin Besar Revolusi Indonesia berdasarkan Ketetapan MPRS Nomor I/MPRS/1960.

10 Pasal 7 UUD 1945 (sebelum amandemen) berbunyi: "Presiden dan Wakil Presiden memegang jabatannya selama masa lima tahun dan sesudahnya dapat dipilih kembali." 
b. Presiden Soekarno telah diangkat menjadi Mandataris Majelis Permusyawaratan Rakyat Sementara dengan kekuasaan penuh berdasarkan Ketetapan MPRS Nomor II/MPRS/1960.

c. Selama perjalanan Revolusi Nasional Indonesia, Bung Karno sebagai Pemimpin Besar Revolusi Indonesia telah berhasil memimpin Revolusi hingga mencapai kemenangankemenangan.

d. Pribadi Bung Karno merupakan perwujudan perpaduan pimpinan Revolusi dan pimpinan negara serta merupakan pemersatu dari seluruh kekuatan rakyat revolusioner.

Materi muatan Ketetapan MPRS produk MPRS periode 1966-1972 terdapat materi muatan yang bersifat pengaturan dan materi muatan yang bersifat penetapan. MPRS pada periode ini juga mengeluarkan Ketetapan MPRS Nomor XX/MPRS/1966 untuk terwujudnya kepastian dan keserasian hukum. Untuk pertama kalinya dibentuk sebuah produk hukum tentang jenis dan tata urutan peraturan perundang-undangan. Akan tetapi, materi muatan Ketetapan MPRS yang dibentuk oleh MPRS periode 19661972 ini lebih merupakan kekecewaan MPRS terhadap kepemimpinan Presiden Soekarno.

Kekecewaan MPRS terhadap Presiden Soekarno dipicu oleh terjadinya peristiwa pemberontakan G-30-S/PKI. ${ }^{11}$ Pada persidangan pertama MPRS periode 19661972 (Sidang Umum Keempat MPRS) Ketetapan MPRS yang dihasilkan antara lain adalah Ketetapan MPRS Nomor XVIII/ MPRS/1966 Tentang Peninjauan kembali Ketetapan MPRS Nomor III/MPRS/1963 (Tentang Pengangkatan Pemimpin Besar Revolusi Indonesia Bung Karno menjadi

11 Untuk G.30 S./PKI, Presiden Soekarno memakai kata Gestok (gerakan satu Oktober). Dalam Pelengkap Pidato Nawaksara Presiden menyatakan "saya memang selalu memakai kata Gestok. Pembunuhan kepada jenderal-jenderal dan ajudan dan pengawal-pengawal terjadi pada 1 Oktober pagi-pagi sekali. Saya menyebutnya "gerakan satu Oktober", singkatnya Gestok."
Presiden Seumur Hidup). Pasal 2 Ketetapan MPRS Nomor XVIII/MPRS/1966 menyatakan bahwa penarikan kembali Ketetapan MPRS Nomor III/MPRS/1963 tidak mempengaruhi masa jabatan Presiden Soekarno sampai ada Ketetapan lain dari Majelis Permusyawaratan Rakyat hasil pemilihan umum.

Materi muatan Ketetapan MPRS yang dihasilkan pada Sidang Istimewa MPRS Tahun $1967^{12}$ adalah puncak kekecewaan terhadap Presiden Soekarno atas peristiwa

12 Sidang Istimewa MPRS tahun 1967 diselenggarakan berdasarkan permintaan DPR-GR untuk memberhentikan Presiden Soekarno dari jabatan Presiden/Mandataris MPRS dan mengangkat Letnan Jenderal Soeharto sebagai Pejabat Presiden/ Mandataris. Hal tersebut terjadi karena DPR-GR dalam menilai "Nawaksara" beserta pelengkapnya berpendapat bahwa "Kepemimpinan Presiden Soekarno secara konstitusional, politis/ideologis membahayakan keselamatan bangsa, negara, dan Pancasila." (isi Resolusi dan Memorandum DPR-GR tertanggal 9 Pebruari 1967).

Nawaksara merupakan judul pidato pertanggungjawaban yang disampaikan oleh Presiden Soekarno di depan Sidang Umum Keempat MPRS tahun 1966. Rakyat yang merasa telah dikhianati oleh peristiwa pemberontakan G-30-S/ PKI mengharapkan kejelasan pertanggungjawaban Presiden Soekarno mengenai pemberontakan G-30-S/PKI. Tetapi pidato pertanggungjawaban Presiden Soekarno tidak memuaskan MPRS.

Menanggapi pidato pertanggungjawaban tersebut kemudian MPRS mengeluarkan Keputusan MPRS RI Nomor 5/MPRS/1966 tentang Tanggapan Majelis Tehadap Pidato Presiden/Mandataris MPRS di depan Sidang Umum IV MPRS pada tanggal 22 Juni 1966 yang Berjudul Nawaksara. Dalam Keputusan MPRS tersebut MPRS meminta kepada Presiden Soekarno untuk melengkapi laporan pertanggungjawabannya kepada MPRS, khususnya mengenai sebab-sebab terjadinya peristiwa G-30-S/ PKI beserta epilognya dan kemunduran ekonomi serta akhlak.

Presiden Soekarno memenuhi permintaan MPRS untuk melengkapi pidato pertanggungjawabannya. Dalam surat tertanggal 10 Januari 1967 Nomor 01/ Pres/67, perihal Pelengkapan Pidato Nawaksara, Presiden menyampaikan bahwa dirinyapun mengutuk Gestok. Presiden Soekarno juga mempertanyakan mengapa dirinya saja yang diminta pertanggungjawaban atas terjadinya G-30-S/PKI. Akan tetapi "Pelengkap Nawaksara" ternyata juga tidak memenuhi harapan. Setelah membahas Surat Presiden tentang Perlengkapan Pidato Nawaksara, berdasarkan hasil musyawarah pimpinan MPRS tanggal 21 Januari 1967, pimpinan MPRS berkesimpulan bahwa Presiden Soekarno alpha memenuhi ketentuan-ketentuan konstitusional. 
G-30-S/PKI. Kekuasaan Presiden Soekarno dan predikatnya sebagai Pemimpin Besar Revolusi dicabut.

Ketetapan MPRS Nomor XXXIII/ MPRS/1967 Tentang Pencabutan Kekuasaan Pemerintahan Negara dari Presiden Soekarno dikeluarkan dasar pertimbangannya adalah ditolaknya pidato Presiden yang berjudul "Nawaksara" dan "Pelengkap Nawaksara", Presiden/Mandataris MPRS telah menyerahkan kekuasaan pemerintahan negara kepada Soeharto sebagai pengemban Ketetapan MPRS Nomor IX/MPRS/1966, dan berdasarkan laporan tertulis Panglima Operasi Pemulihan Keamanan dan Ketertiban/ Pengemban Ketetapan MPRS Nomor IX/ MPRS/1966 dalam Suratnya Nomor R-032/'67 tanggal 1 Pebruari 1967 yang dilengkapi dengan pidato laporannya di hadapan Sidang Istimewa Majelis Permusyawaratan Rakyat Sementara, berpendapat bahwa ada petunjuk-petunjuk, yang Presiden Soekarno telah melakukan kebijaksanaan yang secara tidak langsng menguntungkan G-30-S/PKI dan melindungi tokoh-tokoh G-30-S/PKI. Dalam Ketetapan MPRS Nomor XXXIII/ MPRS/1967 juga melarang Presiden Soekarno melakukan kegiatan politik sampai dengan pemilihan umum.

Ketetapan MPRS Nomor XXXVI MPRS/1967 tentang Pencabutan Ketetapan MPRS Nomor XVII/MPRS/1966 Tentang Pemimpin Besar Revolusi dikeluarkan dengan dasar pertimbangan gelar Pemimpin Besar Revolusi yang diberikan kepada Presiden Soekarno tidak membawa wewenang hukum dan karenanya dianggap sebagai gelar biasa.

Materi muatan Ketetapan MPRS yang dihasilkan pada Sidang Umum Kelima MPRS tanggal 21-27 Maret 1968 merupakan tindak lanjut dari materi muatan Ketetapan MPRS yang dihasilkan dalam Sidang Istimewa MPRS Tahun 1967. Presiden Soekarno telah dicabut kekuasaannya dan Soeharto diangkat sebagai Presiden Republik Indonesia dengan Ketetapan MPRS Nomor XLIV/ MPRS/1968. Semua Ketetapan MPRS yang materi muatannya merupakan penegasan kembali pidato Presiden Soekarno juga telah dicabut dengan Ketetapan MPRS Nomor XXXVIII/MPRS/1968.

\section{Materi Muatan Ketetapan MPR Masa Pemerintahan Orde Baru}

Pada masa pemerintahan Orde Baru, terdapat enam periode keanggotaan MPR yaitu MPR periode1972-1977, MPR periode 1977-1982, MPR periode 1982-1987, MPR periode 1987-1992, MPR periode 19921997, dan MPR periode 1997-2002. Hampir seluruh materi muatan Ketetapan MPR pada masa pemerintahan Orde Baru sama, yaitu berisi Peraturan Tata Tertib MPR, penetapan GBHN, dan Pengangkatan Presiden dan Wakil Presiden. Hanya pada MPR periode tertentu saja menghasilkan Ketetapan MPR yang materi muatannya berbeda dari yang lain.

Materi muatan Ketetapan MPR periode 1972-1977 ada yang bersifat pengaturan dan ada yang bersifat penetapan. Berbeda dengan materi muatan Ketetapan MPR sebelumnya, pada masa ini materi muatan Ketetapan MPR lebih pada usaha untuk mencegah agar kekuatan politik orde lama tidak muncul lagi.

Materi muatan Ketetapan MPR periode 1977-1982 sama dengan materi muatan Ketetapan MPR periode sebelumnya. Pada periode ini terdapat Ketetapan MPR tentang Pedoman Penghayatan dan Pengamalan Pancasila (Ekaprasetya Pancakarsa). Ketetapan MPR ini dimaksudkan untuk mencegah bangkitnya bahaya laten komunis yang berupaya untuk mengubah dasar negara Pancasila.

Pada periode 1982-1987, terdapat materi muatan Ketetapan MPR tentang Referendum. $\mathrm{Hal}$ ini dilakukan karena keinginan MPR untuk mempertahankan Undang-Undang Dasar 1945, tidak berkehendak dan tidak melakukan perubahan terhadap UUD 1945 serta akan melaksanakannya secara murni dan konsekuen. Jika MPR berkehendak untuk mengubah UUD 1945, maka harus terlebih dahulu meminta pendapat rakyat melalui referendum. Ketentuan Ketetapan MPR Tentang Referendum ini dapat dikatakan bertentangan dengan ketentuan Pasal 37 
UUD 1945, karena dalam ketentuan Pasal 37 UUD 1945, untuk mengubah UUD 1945 tidak ada keharusan untuk mengadakan referendum.

Materi muatan Ketetapan MPR Periode 1987-1992, dan periode 1992-1997 sama dengan periode sebelumnya, yaitu tentang Peraturan Tata Tertib MPR, Garis-garis Besar Haluan Negara, dan pengangkatan Presiden dan Wakil Presiden.

Materi muatan Ketetapan MPR periode 1997-2002 yang dihasilkan pada Sidang Umum MPR tahun 1998 sama dengan materi muatan Ketetapan MPR periode sebelumnya. Penyelenggaraan Sidang Umum MPR tahun 1998 ini diadakan pada saat bangsa Indonesia dilanda krisis moneter dan keuangan. Hilangnya kepercayaan masyarakat kepada pemerintah bermuara pada berhentinya Presiden Soeharto dari jabatannya. Dengan Keputusan DPR Nomor 20/DPR RI/1998, DPR secara resmi meminta kepada MPR untuk menyelenggarakan Sidang Istimewa. Untuk menjawab permintaan DPR tersebut MPR bersepakat untuk menyelenggarakan Sidang Istimewa MPR yang dituangkan dalam Keputusan MPR RI Nomor 10/PIMP/1998.

Materi muatan Ketetapan MPR hasil Sidang Istimewa tahun 1998 merupakan upaya untuk melakukan perombakan total demi menjaga persatuan dan kesatuan bangsa, mengembalikan martabat Negara Kesatuan Republik Indonesia, dan membangun bangsa berdasarkan kehidupan bangsa yang berkeadilan, dan memenuhi aspirasi masyarakat yang menuntut diselenggarakannya pemilihan umum yang dipercepat. Jika pada periode sebelumnya pada masa pemerintahan Orde Baru materi muatan Ketetapan MPR hampir sama seluruhnya, maka materi muatan Ketetapan MPR hasil Sidang Istimewa setelah berhentinya Presiden Soeharto dari jabatannya berupaya untuk menghilangkan bayang-bayang Soeharto. Misalnya Ketetapan MPR Nomor XVIII/ MPR/1998 yang mencabut Ketetapan Nomor II/MPR/1978 Tentang Pedoman Penghayatan dan Pengamalan Pancasila
(Ekaprasetya Pancakarsa). Ketetapan MPR tersebut dicabut karena dianggap sebagai upaya Presiden Soeharto untuk mempertahankan kekuasaannya.

\section{Materi Muatan Ketetapan MPR Masa Reformasi}

Pada Era Reformasi, setelah pemilihan umum tahun 1999 sampai saat ini terdapat empat periode keanggotaan MPR yaitu MPR periode 1999-2004, MPR periode 2004-2009, MPR periode 2009-2014, dan MPR periode 2014-2019.

Pembentukan Ketetapan MPR hanya dilakukan oleh MPR periode 1999-2004, karena setelah UUD 1945 diamandemen, MPR tidak dapat lagi mengeluarkan ketetapanketetapan yang bersifat mengatur (regeling). MPR tidak boleh lagi membuat ketetapan yang bersifat mengatur dalam bentuk peraturan perundang-undangan kecuali pengaturan yang bersifat internal seperti tentang Tata Tertib. MPR memang masih dapat mengeluarkan ketetapan, tetapi tidak boleh berbentuk peraturan perundang-undangan (regeling) melainkan berbentuk penetapan (beschikking) atau, kalau mengatur, sifatnya internal. ${ }^{13}$

Sejak MPR hasil pemilihan umum tahun 2004 sampai sekarang, MPR tidak pernah mengeluarkan produk hukum MPR yang berupa Ketetapan MPR. Produk hukum Ketetapan MPR terakhir kali dibentuk pada tahun 2003, yaitu Ketetapan MPR Nomor I/MPR/2003 tentang Peninjauan Terhadap Materi dan Status Hukum Ketetapan Majelis Permusyawaratan Rakyat Sementara dan Ketetapan Majelis Permusyawaratan Rakyat Republik Indonesia Tahun 1960 sampai dengan Tahun 2002. Ketetapan MPR Nomor I/MPR/2003 ini meninjau seluruh materi Ketetapan MPRS dan Ketetapan MPR dan memberikan status hukumnya (berjumlah seratus tiga puluh sembilan). Ketetapan MPRS dan Ketetapan MPR yang berjumlah seratus tiga puluh sembilan dikelompokkan menjadi enam, yaitu:

13 Moh. Mahfud MD, 2010, Pedebatan Hukum Tata Negara Pasca Amandemen Konstitusi, Rajawali Pers, Raja Grafindo Persada, Jakarta, hlm. 54. 
a. Ketetapan Majelis Permusyawaratan Rakyat Sementara dan Ketetapan Majelis Permusyawaratan Rakyat Republik Indonesia yang dicabut dan dinyatakan tidak berlaku (berjumlah delapan)

b. Ketetapan Majelis Permusyawaratan Rakyat Sementara dan Ketetapan Majelis Permusyawaratan Rakyat Republik Indonesia yang dinyatakan tetap berlaku dengan ketentuan masing-masing (berjumlah tiga)

c. Ketetapan Majelis Permusyawaratan Rakyat Republik Indonesia yang dinyatakan tetap berlaku sampai dengan terbentuknya pemerintahan hasil pemilihan umum tahun 2004 (berjumlah delapan)

d. Ketetapan Majelis Permusyawaratan Rakyat Sementara dan Ketetapan Majelis Permusyawaratan Rakyat Republik Indonesia yang tetap berlaku sampai dengan terbentuknya undangundang (berjumlah sebelas)

e. Ketetapan Majelis Permusyawaratan Rakyat Republik Indonesia tentang Peraturan Tata Tertib Majelis Permusyawaratan Rakyat Republik Indonesia yang dinyatakan masih berlaku sampai dengan ditetapkannya Peraturan Tata Tertib yang baru oleh Majelis Permusyawaratan Rakyat Republik Indonesia hasil pemilihan umum tahun 2004 (berjumlah lima)

f. Ketetapan Majelis Permusyawaratan Rakyat Sementara dan Ketetapan Majelis Permusyawaratan Rakyat Republik Indonesia yang tidak perlu dilakukan tindakan hukum lebih lanjut, baik karena bersifat einmalig (final), telah dicabut, maupun telah selesai dilaksanakan (berjumlah seratus empat)

Kewenangan MPR sebagaimana diatur dalam Pasal 3 UUD Negara Republik Indonesia Tahun 1945, yaitu mengubah dan menetapkan undang-undang dasar, melantik Presiden dan/atau Wakil Presiden, memberhentikan Presiden dan/atau Wakil Presiden dalam masa jabatannya menurut undang-undang dasar, adalah bersifat beschikking (kecuali mengubah dan menetapkan UndangUndang Dasar), sehingga produk hukum MPR berdasarkan kewenangannya bersifat beschikking pula (kecuali Perubahan UndangUndang Dasar). Selain itu, berdasarkan Undang-Undang Nomor 10 Tahun 2004 tentang Pembentukan Peraturan Perundangundangan, Ketetapan MPR tidak termasuk dalam jenis peraturan perundang-undangan sehingga tidak dimasukkan ke dalam hierarki peraturan perundang-undangan.

Materi muatan Ketetapan MPR pada era reformasi ada yang bersifat pengaturan, dan ada pula materi muatan yang berupa penetapan, akan tetapi sebagian besar isinya dimaksudkan untuk mengadakan pembatasan-pembatasan kekuasaan eksekutif Presiden dan pemberdayaan lembaga-lembaga negara yang lain.

Berdasarkan uraian di atas penulis memberikan analisis bahwa materi muatan Ketetapan MPR ada yang bersifat umum/ pengaturan, dan oleh karenanya dapat digolongkan sebagai peraturan perundangundangan, ada materi muatan Ketetapan MPR yang mengikat individu/konkrit individual yang tidak dapat digolongkan sebagai peraturan perundang-undangan. Selain kedua materi muatan yang bersifat pengaturan dan yang bersifat konkrit/individual, terdapat juga materi muatan Ketetapan MPR yang tidak termasuk keduanya.

Materi muatan Ketetapan MPR yang tidak termasuk peraturan perundang-undangan dan tidak termasuk pula yang bersifat konkrit individual adalah Ketetapan MPR yang materi muatannya merupakan sebuah pernyataan kehendak atau pernyataan keinginan, komitmen, atau deklarasi, atau perintah MPR kepada lembaga pembuat undang-undang.

Beragamnya materi muatan Ketetapan MPR, dianalisis dari pengertian peraturan perundang-undangan yang dikemukakan oleh para ahli dan prosedur pembentukan peraturan perundang-undangan, maka Ketetapan MPR tidak dapat dikategorikan sebagai peraturan perundang-undangan. 
Ciri-ciri peraturan perundang-undangan yang dikemukakan oleh Satjipto Rahardjo sebagaimana diuraikan pada Bab terdahulu bahwa ciri pertama, peraturan perundangundangan bersifat umum dan komprehensif, yang dengan demikian merupakan kebalikan dari sifat khusus dan terbatas. Ketetapan MPR ada yang bersifat umum dan ada yang bersifat individu. Ketetapan MPR yang bersifat umum dapat dikategorikan sebagai peraturan perundang-undangan, misalnya Ketetapan MPR tentang Garis-garis Besar Haluan Negara. Sementara itu, Ketetapan MPR yang bersifat individual tidak dapat dikategorikan sebagai peraturan perundangundangan, misalnya Ketetapan MPR tentang Pengangkatan Presiden dan Wakil Presiden. Ciri kedua, peraturan perundang-undangan bersifat universal dan diciptakan untuk menghadapi peristiwa-peristiwa yang akan datang yang belum jelas bentuk konkritnya. Oleh karena itu, ia tidak dapat dirumuskan untuk mengatasi peristiwa-peristiwa tertentu saja. Materi muatan Ketetapan MPR ada yang bersifat konkrit dan dibentuk untuk mengatasi peristiwa-peristiwa tertentu saja, misalnya Ketetapan MPRS tentang Pencabutan Bintang Maha Putera Kelas III dari D.N. Aidit. Ciri ketiga, peraturan perundang-undangan memiliki kekuatan untuk mengoreksi dan memperbaiki dirinya sendiri. Ketetapan MPR yang berlaku sekarang ini tidak memiliki kekuatan untuk mengoreksi dan memperbaiki dirinya sendiri karena kewenangan MPR saat sekarang ini tidak memungkinkan MPR untuk membentuk Ketetapan MPR yang materinya bersifat pengaturan. MPR selama dua periode masa jabatannya (2004-2009 dan 20092014) tidak pernah membentuk Ketetapan MPR untuk mengoreksi Ketetapan MPR yang masih dinyatakan berlaku.

Berkaitan dengan UUD 1945, ada materi muatan yang sesuai dengan UUD 1945, dan ada materi muatan yang bertentangan dengan UUD 1945. Materi muatan Ketetapan MPR yang sesuai dengan Undang-Undang Dasar 1945 misalnya tentang Garis-garis Besar Haluan Negara, Pengangkatan Presiden dan Wakil Presiden. Materi muatan Ketetapan
MPR yang tidak sesuai atau bertentangan dengan Undang-Undang Dasar 1945 misalnya Ketetapan MPRS tentang Pengangkatan Presiden Seumur Hidup, dan Ketetapan MPR tentang Referendum.

Materi muatan Ketetapan MPR dari masa ke masa, seiring dengan pergantian kepemimpinan nasional dan perubahan sistem ketatanegaraan selalu mengalami perubahan. Perubahan zaman, pergantian sistem ketatanegaraan, dan pergantian kekuasaan menentukan materi muatan yang diatur di dalam Ketetapan MPR.

\section{Penutup}

\section{Simpulan}

Ketetapan MPR berubah materi muatannya, seiring dengan pergantian pemerintahan dan perubahan UndangUndang Dasar. Pada masa pemerintahan Orde Lama, materi muatan Ketetapan MPRS ada yang berupa pengaturan, ada yang berupa penetapan, dan ada yang merupakan penegasan kembali pidato Presiden. Pada masa pemerintahan Orde Lama ini terdapat dua periode keanggotaan MPRS yaitu MPRS periode 1960-1966 dan MPRS periode 1966-1972. Ketetapan MPRS periode 1960-1966 materi muatannya ada yang merupakan penegasan kembali pidato Presiden Soekarno, misalnya, Ketetapan MPRS tentang Manifesto Politik Republik Indonesia, dan ada materi muatan yang bertentangan dengan Undang-Undang Dasar 1945, misalnya Ketetapan MPRS tentang pengangkatan Bung Karno sebagai presiden seumur hidup. Ketetapan MPRS periode 1966-1972 materi muatannya lebih merupakan kekecewaan MPRS terhadap kepemimpinan Presiden Soekarno. Kekecewaan MPRS ini sampai pada puncaknya dengan dikeluarkannya Ketetapan MPRS tentang Pencabutan Kekuasaan Pemerintahan Negara dari Presiden Soekarno.

Ketetapan MPR pada masa pemerintahan Orde Baru lebih pada usaha untuk mencegah agar kekuatan politik masa Orde Lama tidak muncul kembali. Materi muatan Ketetapan MPR 
pada masa Reformasi sebagian besar isinya dimaksudkan untuk mengadakan pembatasanpembatasan kekuasaan eksekutif (Presiden) dan pemberdayaan lembaga-lembaga negara lain. Pembentukan Ketetapan MPR dipengaruhi oleh perubahan kedudukan dan kewenangan yang diberikan kepada MPR. Materi muatan Ketetapan MPR pada masa pemerintahan Orde Lama, Orde Baru, dan Era Reformasi dapat digambarkan sebagai berikut:

Materi Muatan Ketetapan MPR

\begin{tabular}{|c|c|c|}
\hline Orde Lama & Orde Baru & Era Reformasi \\
\hline \begin{tabular}{|l} 
1. MPRS periode 1960-1965: \\
- Penegasan kembali pidato \\
Presiden Soekarno \\
- Bertentangan dengan \\
UUD 1945 (pengangkatan \\
Presiden seumur hidup) \\
2. MPRS periode 1966-1972: \\
Kekecewaan terhadap \\
kepemimpinan Presiden \\
Soekarno hingga pada \\
puncaknya dengan mencabut \\
kekuasaan dari Presiden \\
Soekarno
\end{tabular} & $\begin{array}{l}\text { 1. Tata tertib MPR } \\
\text { 2. Pengangkatan Presiden } \\
\text { dan Wakil Presiden } \\
\text { 3. GBHN } \\
\text { 4. Terdapat Ketetapan } \\
\text { MPR yang bertentangan } \\
\text { dengan UUD } 1945 \text { yaitu } \\
\text { Ketetapan MPR tentang } \\
\text { Referendum }\end{array}$ & $\begin{array}{l}\text { 1. Awal reformasi: menghilangkan } \\
\text { bayang-bayang Orde Baru dengan } \\
\text { mencabut Ketetapan MPR tentang } \\
\text { Eka Prasetya Panca Karsa atau } \\
\text { P4 (Pedoman Penghayatan dan } \\
\text { Pengalaman Pancasila) } \\
\text { 2. Reformasi: } \\
\text { - mengadakan pembatasan- } \\
\text { pembatasan kekuasaan eksekutif } \\
\text { - pemberdayaan lembaga-lembaga } \\
\text { negara lain }\end{array}$ \\
\hline
\end{tabular}

\section{Saran-saran.}

Materi muatan Ketetapan MPR yang berbeda-beda mulai masa pemerintahan Orde Lama, Orde Baru, dan Era Reformasi, ada yang bersifat beschikking dan ada yang bersifat regeling. Jika Ketetapan MPR masuk dalam hierarki peraturan perundang-undangan, maka seharusnya materi muatan Ketetapan MPR tidak bersifat beschikking, tetapi bersifat regeling. Produk hukum MPR yang bersifat beschikking seharusnya dikeluarkan dalam bentuk Keputusan MPR, bukan Ketetapan MPR.

\section{DAFTAR PUSTAKA}

A. Hamid S. Attamimi, 1990, Peranan Keputusan Presiden Republik Indonesia dalam Penyelenggaraan Pemerintahan Negara, Suatu Studi Analisis Mengenai Keputusan Presiden yang Berfungsi Pengaturan dalam Kurun Waktu Pelita I - Pelita IV, Disertasi untuk memperoleh Gelar Doktor dalam IImu Hukum pada Universitas Indonesia Fakultas Pascasarjana, Jakarta.

Moh. Kusnardi dan Bintan R. Saragih, 1980, Susunan Pembagian Kekuasaan Menurut Sistem Undang-Undang Dasar 1945, Gramedia, Jakarta.

Moh. Mahfud MD, 2010, Pedebatan Hukum Tata Negara Pasca Amandemen Konstitusi, Rajawali Pers, Raja Grafindo Persada, Jakarta.

Majelis Permusyawaratan Rakyat Republik Indonesia, 2009, Sejarah, Realita, dan Dinamika, Sekretariat Jenderal Majelis Permusyawaratan Rakyat Republik Indonesia.

Undang-Undang Dasar Negara Republik Indonesia Tahun 1945

Ketetapan MPR Nomor I/MPR/1973 tentang Peraturan Tata Tertib Majelis Permusyawaratan Rakyat. Ketetapan MPR Nomor I/MPR/2003 tentang Peninjauan Terhadap Materi dan Status Hukum Ketetapan Majelis Permusyawaratan Rakyat Sementara dan Ketetapan Majelis Permusyawaratan

Rakyat Republik Indonesia Tahun 1960 sampai dengan Tahun 2002.

Undang-Undang Nomor 10 Tahun 2004 tentang Pembentukan Peraturan Perundang-undangan Undang-Undang Nomor 12 Tahun 2011 tentang Pembentukan Peraturan Perundang-undangan Undang-Undang Nomor 17 Tahun 2014 tentang Majelis Permusyawaratan Rakyat, Dewan Perwakilan Rakyat, Dewan Perwakilan Daerah, dan Dewan Perwakilan Rakyat Daerah 